\title{
Sebaceous gland carcinoma in upper eyelid
}

\section{Carcinoma de glándulas sebáceas en párpado superior}

\author{
René H. Parada-Vásquez ${ }^{1 *}$, Juan P. Medina-López ${ }^{2}$ and Rogerio Martins-Baia ${ }^{3}$
}

${ }^{1}$ Anterior segment fellow; ${ }^{2}$ Third year ophthalmology resident; ${ }^{3} \mathrm{Head}$ of Oculoplastic Service. Instituto de la Visión, Hospital La Carlota, Montemorelos, Nuevo León, Mexico

A 68-year-old male presented with an ulcerated lesion in the left orbit, with irregular borders and loss of structure from the middle to the inner third of the upper eyelid (Fig. 1), madarosis in the free margin of the eyelid around the lesion (Fig. 2), cornea with superior sectoral edema and punctate staining. Fundus exploration was unremarkable. He had a history of radiotherapy 3 years ago, due to an unspecified tumor in the left upper eyelid. An incisional biopsy reported a neoplasm composed of epithelioid cells with pronounced pleomorphism, diagnosing a differentiated, invasive, ulcerated and primary sebaceous gland carcinoma of the left eyelid ${ }^{1}$.

\section{Ethical disclosures}

Protection of human and animal subjects. The authors declare that no experiments were performed on humans or animals for this study.

Confidentiality of data. The authors declare that they have followed the protocols of their work center on the publication of patient data.

Right to privacy and informed consent. The authors have obtained the written informed consent of the patients or subjects mentioned in the article. The corresponding author is in possession of this document.

\section{Funding}

The author(s) received no specific funding for this work.

\section{Conflicts of interest}

The authors declare no conflicts of interest.

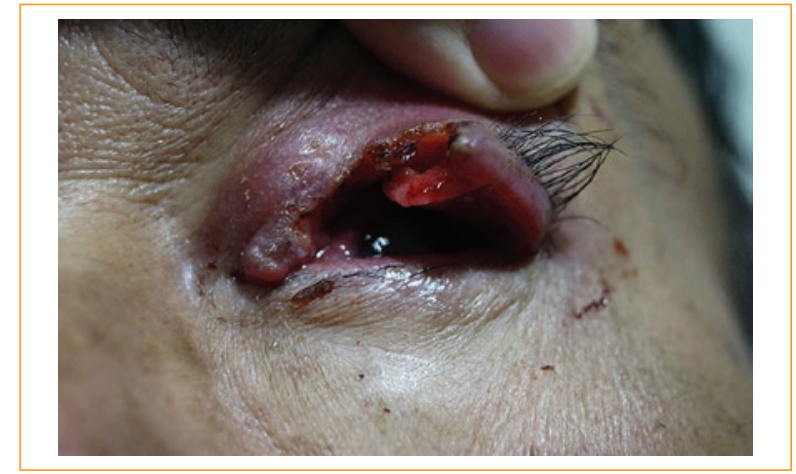

Figure 1. Ulcerated lesion with irregular borders and loss of upper eyelid structure.

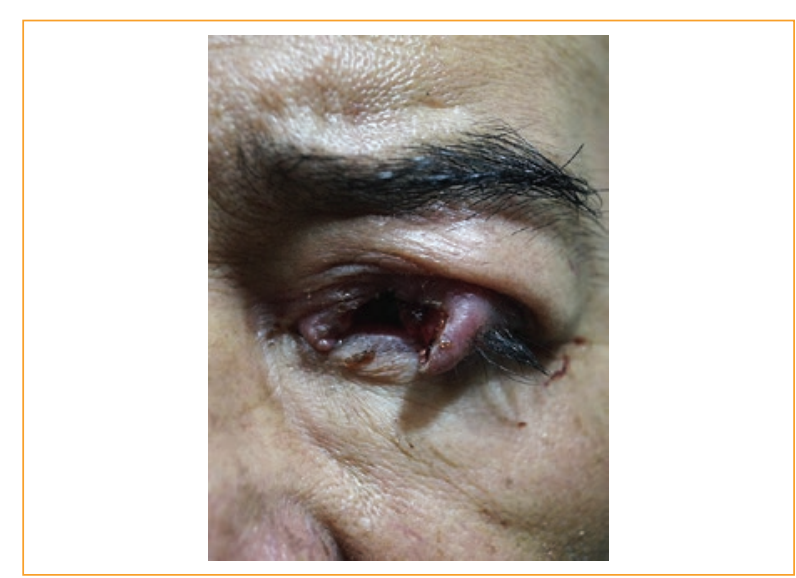

Figure 2. Loss from the middle to the inner third of the upper eyelid, with madarosis.

\section{Reference}

1. Kanski JJ, Bowling B. Kanski Oftalmología clínica. Séptima edición España: Elsevier; 2012. p. 20-1.

\section{Correspondence:}

*René Hernán Parada-Vásquez 